\title{
Silicon Improves the Production of High Antioxidant or Structural Phenolic Compounds in Barley Cultivars under Aluminum Stress
}

\author{
Isis Vega ${ }^{1,2}$, Miroslav Nikolic ${ }^{3}$, Sofía Pontigo ${ }^{2}$, Karina Godoy ${ }^{2}$, María de La Luz Mora ${ }^{2,4}$ (D) and \\ Paula Cartes ${ }^{2,4, *}$ \\ 1 Doctoral Program in Science of Natural Resources, Universidad de La Frontera, Avenida Francisco Salazar \\ 01145, P.O. Box 54-D, Temuco 4780000, Chile \\ 2 Center of Plant-Soil Interaction and Natural Resources Biotechnology, Scientific and Technological \\ Bioresource Nucleus (BIOREN-UFRO), Universidad de La Frontera, Avenida Francisco Salazar 01145, \\ PO Box 54-D, Temuco 4780000, Chile \\ 3 Plant Nutrition Research Group, Institute for Multidisciplinary Research, University of Belgrade, PO Box 33, \\ Belgrade 11030, Serbia \\ 4 Departamento de Ciencias Químicas y Recursos Naturales, Facultad de Ingeniería y Ciencias, \\ Universidad de La Frontera, Avenida Francisco Salazar 01145, PO Box 54-D, Temuco 4780000, Chile \\ * Correspondence: paula.cartes@ufrontera.cl; Tel.: +56-45-2325431
}

Received: 9 May 2019; Accepted: 10 July 2019; Published: 17 July 2019

\begin{abstract}
Aluminum (Al) toxicity is one of the main growth and yield limiting factors for barley grown on acid soils. Silicon (Si) ameliorates Al toxicity as well as it promotes the phenolic compounds production that have antioxidant or structural role. We evaluated the time-dependent kinetics of $\mathrm{Al}$ and $\mathrm{Si}$ uptake and the impact of $\mathrm{Si}$ on the production of antioxidant- or structural- phenols in barley cultivars at the short-term. Two barley cultivars with contrasting $\mathrm{Al}$ tolerance (Hordeum vulgare 'Sebastian', Al tolerant; and H. vulgare 'Scarlett', Al sensitive), exposed to either $-\mathrm{Al}(0 \mathrm{mM})$ or $+\mathrm{Al}$ $(0.2 \mathrm{mM})$ nutrient solutions without $\mathrm{Si}(-\mathrm{Si})$ or with $2 \mathrm{mM}(+\mathrm{Si})$ were cultured for $48 \mathrm{~h}$. Aluminum and $\mathrm{Si}$ concentration decreased in plants at all harvest times when $\mathrm{Al}$ and $\mathrm{Si}$ were simultaneously supplied; this effect was more noticeable in 'Scarlett'. Nevertheless, Si influenced the antioxidant system of barley irrespective of the $\mathrm{Al}$ tolerance of the cultivar, decreasing oxidative damage and enhancing radical scavenging activity, the production of phenolic compounds, and lignin accumulation in barley with short-term exposure to $\mathrm{Al}$.
\end{abstract}

Keywords: aluminum toxicity; barley; phenolic compounds; lignin

\section{Introduction}

Barley (Hordeum vulgare L.) is used as a feedstock due to its elevated nutritional value, particularly carbohydrates, proteins, vitamins, and phenolic compounds [1]. Barley also contains a large amount of fiber, a well-recognized source of $\beta$-glucans that reduces cholesterol and the glycemic index [2]. One of the main limitations for the production of barley is its sensitivity to soil acidity, which decreases the yield of grains [3]. In acid soils, aluminum (Al) is solubilized as phytotoxic $\mathrm{Al}^{3+}$ ions [4]. This inhibits root growth and nutrient uptake by altering the structure and function of the cell wall and plasma membrane, and therefore limits crop production [4,5]. Furthermore, it has been shown that $\mathrm{Al}$ toxicity increases the formation of reactive oxygen species (ROS) triggering oxidative damage in plant cells $[5,6]$. However, the degree of toxicity differs with the plant species, growth conditions, concentration, and time of exposure to Al stress [4,7]. Barley exhibits considerably higher sensitivity to $\mathrm{Al}$ toxicity than rice, rye, oats, and wheat $[8,9]$. 
Despite $\mathrm{Si}$ is not recognized to be an essential nutrient for vascular plants, it has widely been demonstrated that $\mathrm{Si}$ supply increases crop production, root volume, and leaf density, and also decreases diseases and pest attack in several plant species exposed to biotic and abiotic stresses [10-15]. Over recent years, it has been shown that $\mathrm{Si}$ enhances the primary metabolism by improving photosynthesis $[11,16,17]$ and nutrient uptake [18], as well as the secondary metabolism through stimulation of the production of phenolic compounds with either antioxidant (e.g., flavonoids) or structural (e.g., lignin) functions [19-21]. Therefore, it has been reported that $\mathrm{Si}$ causes improvement in either antioxidant or structural phenols metabolism of plants under stressful environmental conditions $[19,20,22,23]$. This occurs via the regulation of the transcript level or activity of enzymes involved to phenylpropanoid pathway (e.g., phenylalanine ammonia lyase, peroxidase) [23-25], formation of lignin-carbohydrate complexes [26,27], and direct complexation of $\mathrm{Si}$ with polyphenolic compounds [22].

Several reports have suggested that the positive effects of Si on plants are closely related to the high accumulation of this element in different tissues [28,29]. Nevertheless, a differential capacity to take up Si has been reported among plant species and genotypes [28-30]. In general, poaceae species such as barley have been classified as "accumulators", since they can contain up to $1 \%$ of Si in dry matter basis [31]. Recent molecular advances associated with the identification and characterization of $\mathrm{Si}$ transporters in various plant species have been useful to improve the understanding of the benefits that plants can derive from Si uptake [12,28,29]. Accordingly, influx transporters (Lsi1 and Lsi6; belonging to the subgroup of aquaporins Nodulin 26-like intrinsic proteins III) and efflux transporters (Lsi2 and Lsi3; known as anion transporters) have been reported to be responsible for the uptake and transport of $\mathrm{Si}$ in different plant species including barley [29,32-34]. Moreover, the identification of highly conserved features in $\mathrm{Si}$ influx transporter determining the functional selectivity for silicic acid provided new insights into the prediction of Si uptake ability of plants [29,35-37].

Silicon is currently viewed as a sustainable alternative to provide tolerance to various metals including zinc $(\mathrm{Zn})$, iron $(\mathrm{Fe})$, copper $(\mathrm{Cu})$, cadmium $(\mathrm{Cd})$, chromium $(\mathrm{Cr})$, manganese $(\mathrm{Mn})$, arsenic (As), and Aluminum (Al) [10,23,38-42]. Accordingly, the amelioration of Al toxicity by $\mathrm{Si}$ has so far been demonstrated in numerous crops, including rice, wheat, maize, sorghum, ryegrass, and soybean $[12,23,43-45]$. In addition, some research has indicated that Si supply could stimulate plant growth processes and decrease the intensity of lipid oxidative damage [23,44,46]. However, the mechanisms induced by Si against Al stress are not yet entirely clear. Nevertheless, it has been demonstrated that $\mathrm{Si}$ addition in the presence of $\mathrm{Al}$ generates an increase in the culture media $\mathrm{pH}$, and reduces of the availability of phytotoxic $\mathrm{Al}$ for plants, due to the formation of hydroxyaluminosilicates in solution [43]. Furthermore, there is evidence showing internal detoxification of $\mathrm{Al}$ through the formation of aluminosilicates in plant cell walls [43]. The Si-induced exudation of phenolic compounds with the ability to chelate Al has been also reported [47].

Currently, there is evidence shown that Si could alleviate Al toxicity in barley [46]. Nevertheless, to our knowledge there is a dearth of studies regarding the role of $\mathrm{Si}$ in the metabolism of barley, which is one of the most sensitive cereal crops to Al toxicity. Furthermore, the influence of Si on the phenolic metabolism of Al tolerant or sensitive barley genotypes it has not yet been studied. Thus, this study aimed to evaluate the kinetics of $\mathrm{Al}$ and $\mathrm{Si}$ uptake, as well as the impact of $\mathrm{Si}$ on the production of antioxidant or structural phenolic compounds in barley cultivars in the short-term.

\section{Materials and Methods}

\subsection{Hydroponic Experiment}

Two barley (Hordeum vulgare L.) cultivars with differing Al tolerances (H. vulgare 'Scarlett', $\mathrm{Al}$ sensitive, and H. vulgare 'Sebastian', Al tolerant) were selected from a preliminary hydroponic assay based on the growth parameters and oxidative damage in roots of 11 cultivars subjected Al stress (Supplementary Figure S1). Seeds of 'Scarlett' and 'Sebastian' cultivars were surface sterilized by 
immersion in $2 \%(\mathrm{v} / \mathrm{v})$ sodium hypochlorite for $15 \mathrm{~min}$, and then washed five times with deionized water. The sterilized seeds were germinated on moistened filter paper for 10 days. Once germinated, seedlings were transferred to aerated hydroponic culture pots (3L pots; 48 plants per pot) and cultivated in a basal nutrient solution proposed by Taylor and Foy [48]. During the course of the experiment, dilute $\mathrm{HCl}$ or $\mathrm{NaOH}$ was used to adjust daily the $\mathrm{pH}$ of the solution to 4.5. All plants were precultured for 14 days in a basal nutrient solution and the nutrient solution was changed every 5 days. The plants were then grown in nutrient solutions containing either $0 \mathrm{mM} \mathrm{Al}(-\mathrm{Al})$ or $0.2 \mathrm{mM} \mathrm{Al}(+\mathrm{Al}$; applied as $\mathrm{AlCl}_{3}$, Merck KGaA, Darmstadt, Germany) in combination with $0 \mathrm{mM} \mathrm{Si}(-\mathrm{Si}$ ) or $2 \mathrm{mM} \mathrm{Si}$ (+Si; supplied as $\mathrm{Na}_{2} \mathrm{SiO}_{3}$, Merck KGaA, Darmstadt, Germany). The free $\mathrm{Al}^{3+}$ activity in the nutrient solution was calculated using Geochem-EZ [49] and corresponded to $85 \mu \mathrm{M}$. A factorial experimental design completely randomized, considering three replicates per treatment, was used. At harvest, plant tissues (roots and shoots) were sampled at 2, 4, 8, 12, 24, and $48 \mathrm{~h}$ after Al/Si treatments. Subsamples of shoots and roots were harvested and stored at either $-20^{\circ} \mathrm{C}$ or $-70^{\circ} \mathrm{C}$ for biochemical analyses, measurement of dry weight, and determination of the concentrations of $\mathrm{Si}$ and $\mathrm{Al}$.

\subsection{Plant Chemical Analyses}

Mineral concentration of $\mathrm{Al}$ and $\mathrm{Si}$ was determined after fresh plant material was dried at $65^{\circ} \mathrm{C}$ for $48 \mathrm{~h}$. For $\mathrm{Al}$ analysis, root and shoots samples were ashed at $500^{\circ} \mathrm{C}$ during $8 \mathrm{~h}$ and $2 \mathrm{M}$ hydrochloric acid was added. Flame atomic absorption spectrophotometry (FAAS) was used to quantify $\mathrm{Al}$ at $324.7 \mathrm{~nm}$ according to Sadzawka et al. [50]. Silicon concentration was determined by the modified method described by Pavlovic et al. [51]. An acid digestion was carried out by using $0.1 \mathrm{~g}$ of dried plants samples with $5 \mathrm{~mL}$ of $\mathrm{HNO}_{3}$ on a hot plate at $70{ }^{\circ} \mathrm{C}$ for $5 \mathrm{~h}$. Afterward, $1 \mathrm{~mL}$ of $\mathrm{HF}(40 \%)$ and $10 \mathrm{~mL}$ of distilled water were applied, and the samples were left overnight. Then, $5 \mathrm{~mL} 2 \%(\mathrm{w} / \mathrm{v})$ $\mathrm{H}_{3} \mathrm{BO}_{3}$ was added, the flask volume was adjusted to $25 \mathrm{~mL}$ with distilled water, and $\mathrm{Si}$ was determined by FAAS at $251.6 \mathrm{~nm}$.

\subsection{Plant Biochemical Analyses}

Plant samples previously stored at $-70{ }^{\circ} \mathrm{C}$ were used to analyze the total soluble phenols and radical scavenging activity. Total soluble phenols were assayed according to the method of Slinkard and Singleton [52] using Folin-Ciocalteu reagent. Chlorogenic acid was used as standard, and the absorbance was determined in spectrophotometer at $765 \mathrm{~nm}$. Additionally, radical scavenging activity was analyzed using the 2,2-diphenyl-1-picrylhydrazyl (DPPH) method according to Chinnici et al. [53]. The absorbance was spectrophotometrically tested at $515 \mathrm{~nm}$, using Trolox as the standard. The radical scavenging activity was calculated as Trolox equivalents.

Plant lipid peroxidation was monitored by assaying the thiobarbituric acid reactive substances (TBARS) by the method of Du and Bramlage [54]. In this method, the absorbance of the sample is determined at 532, 600, and $440 \mathrm{~nm}$ to minimize the interference generated by TBARS-sugar complexes.

\subsection{Lignin Visualization Assay}

To visualize the lignin distribution in plant tissues, fresh roots, and leaf sections were stained with 0.1\% Safranine O and analyzed using Laser Scanning Confocal Microscopy (CLSM; Olympus FV1000, Arquimed, Japan) at $\lambda$ emission/excitation of $543 / 590 \mathrm{~nm}$, following the methods of Sant' Anna et al. [55]. The images were analyzed with the Image Processing Software (FV10-ASW v0.200c; Olympus, Tokyo, Japan). In addition, the detection of safranine fluorescence was expressed as Relative Fluorescence Unit (RFU). Thus, different regions of interest in each image were selected and the RFU averages calculated. 


\subsection{Data Analysis}

The data were subjected to analysis of variance (ANOVA), and significantly different means between treatments were tested using the least-significant difference (LSD) at a 0.05 significance level of probability. In addition, Pearson correlation was used to evaluate the relationship between two response variables.

\section{Results}

\subsection{Concentration of Si and Al}

Aluminum concentration gradually increased in the roots and shoots of barley cultivars after the $\mathrm{Al}$ application to the hydroponic solution (Figure 1). In general, at $48 \mathrm{~h}$ the $\mathrm{Al}$ sensitive cultivar 'Scarlett' showed a higher tissue $\mathrm{Al}$ concentration than was observed for the Al tolerant cultivar 'Sebastian'. After $48 \mathrm{~h}$, most of the $\mathrm{Al}$ had been accumulated in the shoots of both cultivars, and Al translocation was greater in 'Scarlett' (72\%) than it was in 'Sebastian' (58\%).
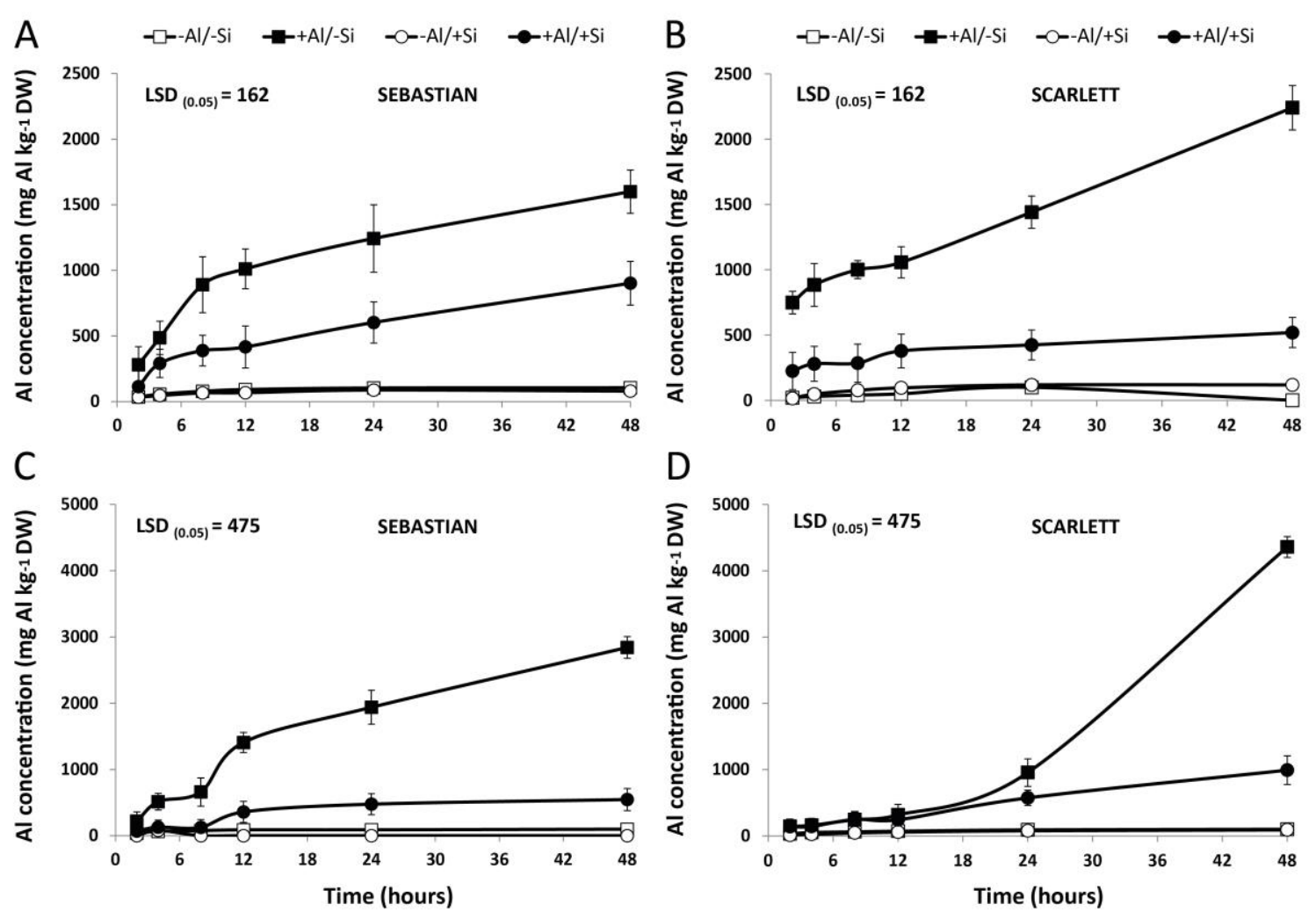

Figure 1. Aluminum concentration of shoots $(\mathbf{A}, \mathbf{B})$ and roots $(\mathbf{C}, \mathbf{D})$ in barley cv. 'Sebastian' (Al-tolerant) and 'Scarlett' (Al-sensitive) harvested at 2, 4, 8, 12, 24, and $48 \mathrm{~h}$. The plants were subjected to $-\mathrm{Al}$ and $+\mathrm{Al}(0.2 \mathrm{mM})$ nutrient solution without $(-\mathrm{Si})$ or with $(+\mathrm{Si})$ supply of $2 \mathrm{mM} \mathrm{Si}$. Values correspond to the average of three replicates \pm standard deviation. Differences between treatments were examined using the LSD test $(p \leq 0.05)$.

In plants supplied with $\mathrm{Al}$, a rapid and significant reduction in the $\mathrm{Al}$ concentration in the roots and shoots was induced by $\mathrm{Si}$, respect to plants treated with $\mathrm{Al}$ alone. Thus, the $\mathrm{Al}$ sensitive cultivar 'Scarlett' showed further reductions in Al concentration of about 63\% (shoots), and 76\% (roots) due to the addition of $\mathrm{Si}$ after $48 \mathrm{~h}$. Likewise, in the $\mathrm{Al}$ tolerant cultivar 'Sebastian', Si addition reduced $\mathrm{Al}$ uptake by about $59 \%$ and $43 \%$ in shoots and roots, respectively. Silicon concentration in the shoots and roots (Figure 2) increased progressively over time by the addition of $\mathrm{Si}$, but when both $\mathrm{Al}$ and $\mathrm{Si}$ were applied, this increase was lower in both cultivars. The highest $\mathrm{Si}$ concentration was recorded after $48 \mathrm{~h}$ 
in plants treated solely with $\mathrm{Si}(-\mathrm{Al} /+\mathrm{Si})$. This increased the Si concentration 9.2-fold (shoots) and 8.8-fold (roots) for the Al tolerant cultivar 'Sebastian' and 12.5-fold (shoots) and 15.2-fold (roots) for the $\mathrm{Al}$ sensitive cultivar 'Scarlett', compared with the control $(-\mathrm{Al} /-\mathrm{Si})$.
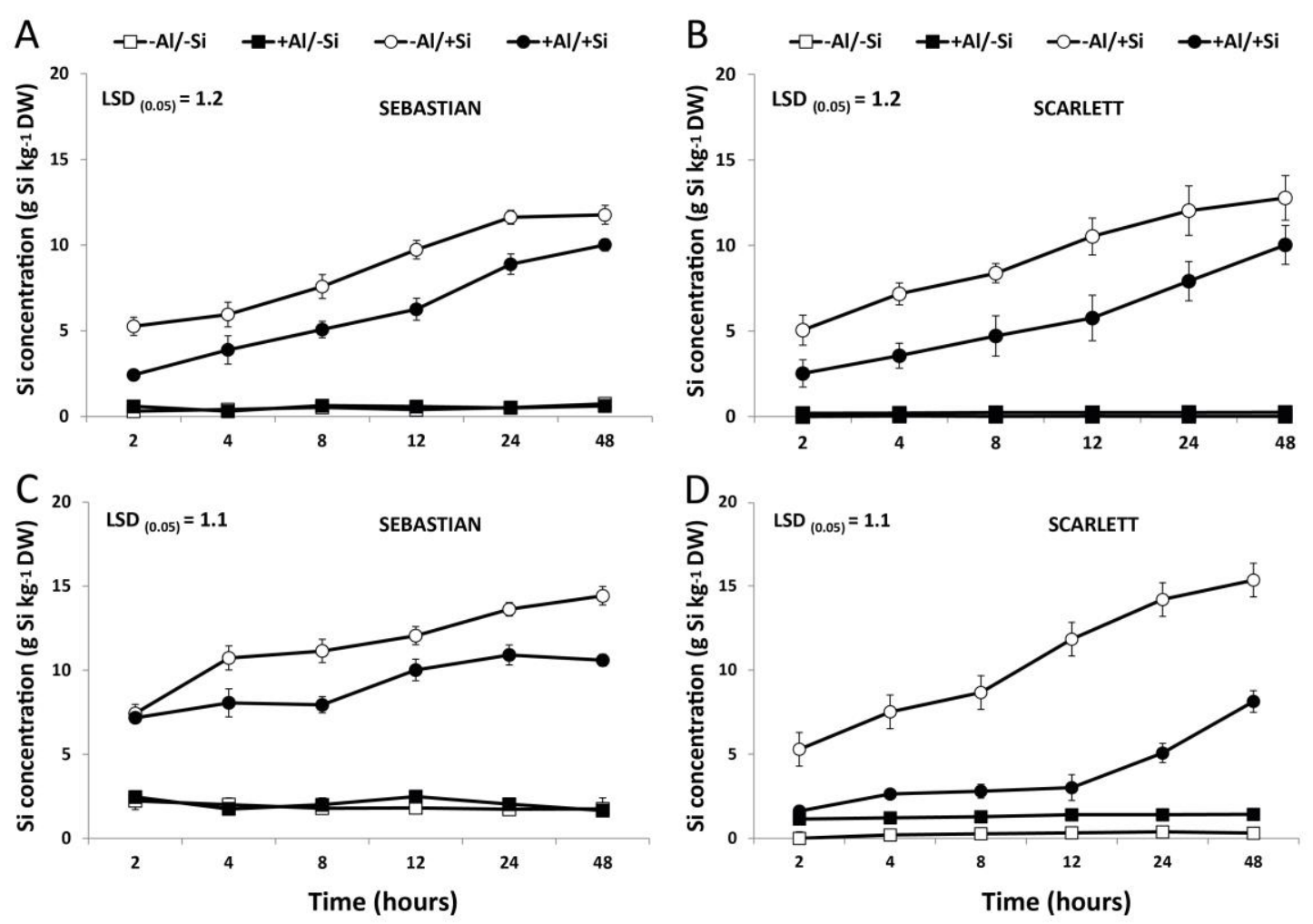

Figure 2. Silicon concentration of shoots (A,B) and roots (C,D) in barley cv. 'Sebastian' (Al-tolerant) and 'Scarlett' (Al-sensitive) harvested at 2, 4, 8, 12, 24, and $48 \mathrm{~h}$. The plants were subjected to $-\mathrm{Al}$ and $+\mathrm{Al}(0.2 \mathrm{mM})$ nutrient solution without $(-\mathrm{Si})$ or with $(+\mathrm{Si})$ supply of $2 \mathrm{mM} \mathrm{Si}$. Values correspond to the average of three replicates \pm standard deviation. Differences between treatments were examined using the LSD test $(p \leq 0.05)$.

\subsection{Antioxidant and Structural Phenols}

The concentration of phenols in plants showed a tendency to increase due to Si addition in both cultivars studied. In the Al tolerant 'Sebastian' cultivar, the highest root phenol concentration was detected in plants supplied with both $\mathrm{Al}$ and $\mathrm{Si}(+\mathrm{Al} /+\mathrm{Si})$ at $48 \mathrm{~h}$, showing a 2-fold increase compared with the control (Figure 3A). In contrast, the lowest concentration of phenols in the roots of the $\mathrm{Al}$ tolerant cultivar 'Sebastian' was found in the $-\mathrm{Al} /+\mathrm{Si}$ treatment at all harvest times. During the course of the experiment, the total phenols of the 'Sebastian' shoots tended to increase with the supply of both $\mathrm{Si}$ and $\mathrm{Al}$; the highest shoot phenol concentration was found after $48 \mathrm{~h}$ (47\% increase, compared with the control) as shown in Figure 3A. 

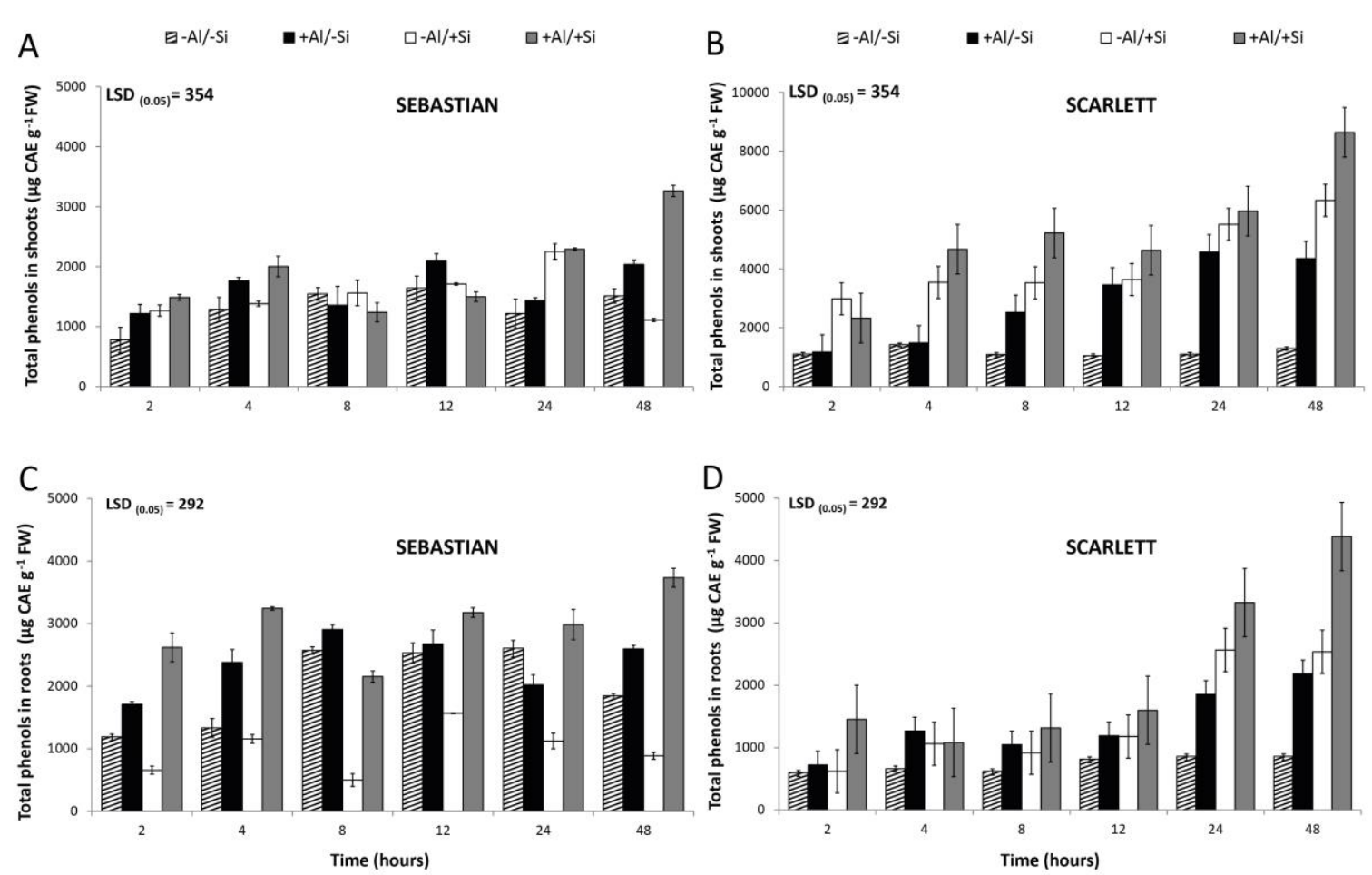

Figure 3. Total phenols of shoots $(\mathbf{A}, \mathbf{B})$ and roots $(\mathbf{C}, \mathbf{D})$ in barley cv. 'Sebastian' (Al-tolerant) and 'Scarlett' (Al-sensitive) harvested at 2, 4, 8, 12, 24, and $48 \mathrm{~h}$. The plants were subjected to $-\mathrm{Al}$ and $+\mathrm{Al}$ $(0.2 \mathrm{mM})$ nutrient solution without $(-\mathrm{Si})$ or with $(+\mathrm{Si})$ supply of $2 \mathrm{mM} \mathrm{Si}$. Values correspond to the average of three replicates \pm standard deviation. Differences between treatments were examined using the LSD test $(p \leq 0.05)$.

On the other hand, in the $\mathrm{Al}$ sensitive cultivar 'Scarlett', the lowest concentration of phenols in the roots was observed in the control treatment $(-\mathrm{Al} /-\mathrm{Si}$ ) at all harvest times (Figure 3D). The total phenols of the roots steadily increased over time with the addition of $\mathrm{Al}$; when both $\mathrm{Al}$ and $\mathrm{Si}$ were added $(+\mathrm{Al} /+\mathrm{Si})$, the total root phenols doubled after $48 \mathrm{~h}$, compared to the Al-treated plants that did not have $\mathrm{Si}$ added $(+\mathrm{Al} /-\mathrm{Si})$.

Similarly, the total phenols of the Al sensitive cultivar 'Scarlett' augmented in the shoots after $2 \mathrm{~h}$ as a consequence of the addition of $\mathrm{Si}$, irrespective of the presence or absence of $\mathrm{Al}$ (Figure $3 \mathrm{~B}$ ). The highest shoot phenol concentration was found after $48 \mathrm{~h}$ in the $+\mathrm{Al} /+\mathrm{Si}$ treatment (6.7-fold increase, compared with the control), whereas the lowest concentration was recorded in $+\mathrm{Al} /-\mathrm{Si}$ and in the control treatments at 2 and $4 \mathrm{~h}$ after treatment.

During the time-course of the experiment, confocal microscopy analysis showed a higher lignin accumulation in the roots of Al sensitive cultivar 'Scarlett' than the Al tolerant cultivar 'Sebastian', irrespective of $\mathrm{Al} / \mathrm{Si}$ added (Figure 4). Compared with non-treated plants, an increment of lignin content was detected in both cultivars as a consequence of $0.2 \mathrm{mM} \mathrm{Al}$ supply, with a further increase being observed in plants simultaneously supplied with $\mathrm{Al}$ and $\mathrm{Si}$. 


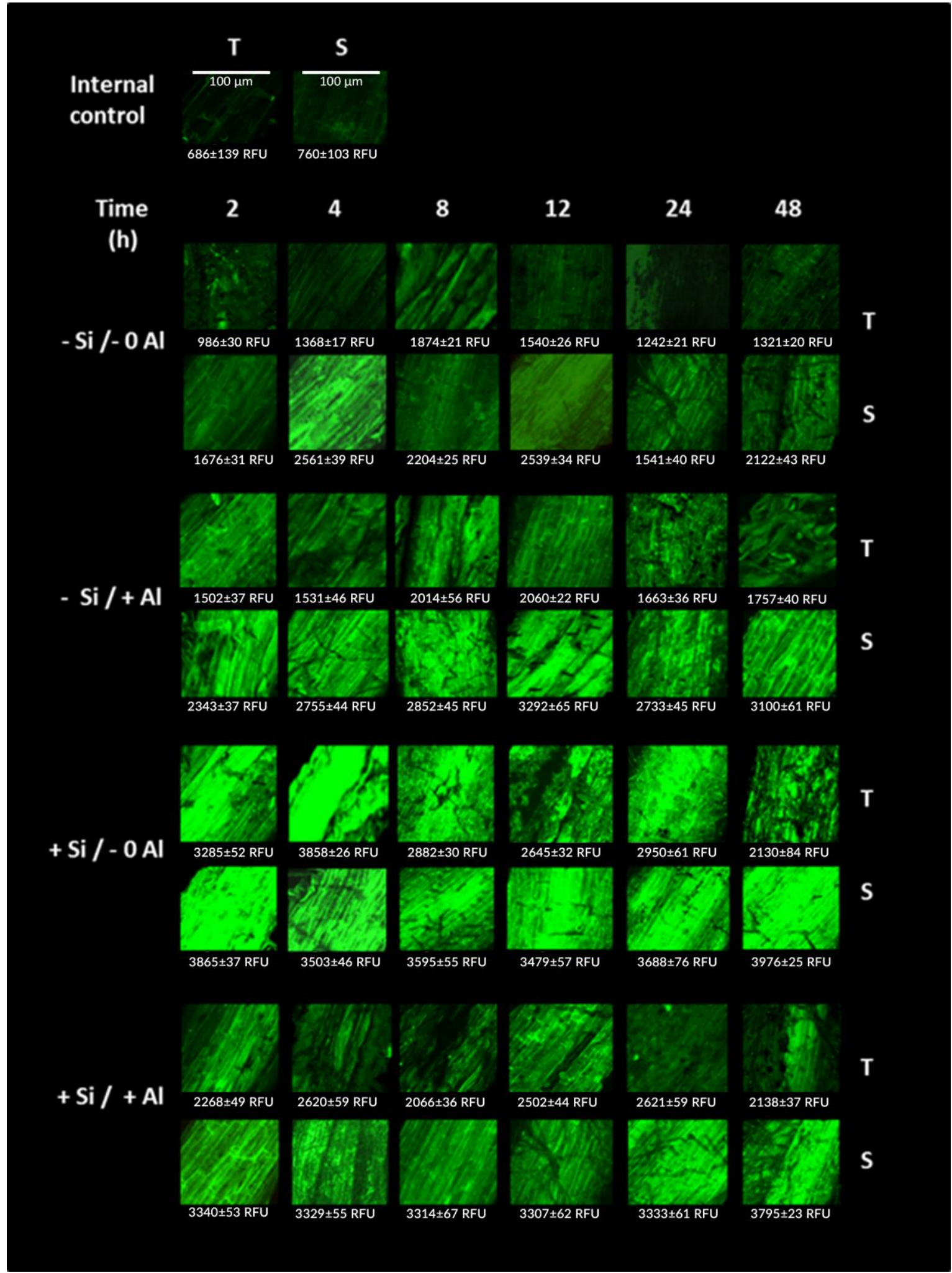

Figure 4. Visualization of lignin contents in barley roots of 'Sebastian', Al-tolerant (T); and 'Scarlett', Al-sensitive (S) harvested at $2,4,8,12,24$, and $48 \mathrm{~h}$. The plants were subjected to $-\mathrm{Al}$ and $+\mathrm{Al}(0.2 \mathrm{mM})$ nutrient solution without $(-\mathrm{Si})$ or with $2 \mathrm{mM} \mathrm{Si}(+\mathrm{Si})$. The detection of safranine fluorescence was expressed as relative fluorescence unit (RFU). 


\subsection{Plant Antioxidant Capacity and Oxidative Damage}

Radical scavenging activity increased with the Al treatment at all harvest times in both $\mathrm{Al}$ sensitive and $\mathrm{Al}$ tolerant cultivars. Moreover, $\mathrm{DPPH}$ and $\mathrm{Al}$ concentration were positively correlated in roots ('Sebastian', $r=0.436 ; p \leq 0.01$ ) and shoots ('Sebastian', $r=0.684 ; p \leq 0.01$; 'Scarlett', $r=0.401 ; p \leq 0.01$ ). A simultaneous application of Al and Si further increased DPPH compared with the control (Figure 5). For the Al tolerant cultivar 'Sebastian', the highest antioxidant capacity (7-fold higher in shoots, and 5-fold higher in roots, compared with the control) was observed after $48 \mathrm{~h}$ of exposure to both $\mathrm{Al}$ and Si (Figure 5A,C). For the Al-sensitive cultivar 'Scarlett', the highest increase in the antioxidant capacity was also observed after $48 \mathrm{~h}$ of exposure, as a consequence of the simultaneous addition of $\mathrm{Si}$ and Al (9-fold higher in shoots and 10-fold higher in roots as compared to the control; Figure 5B,D).
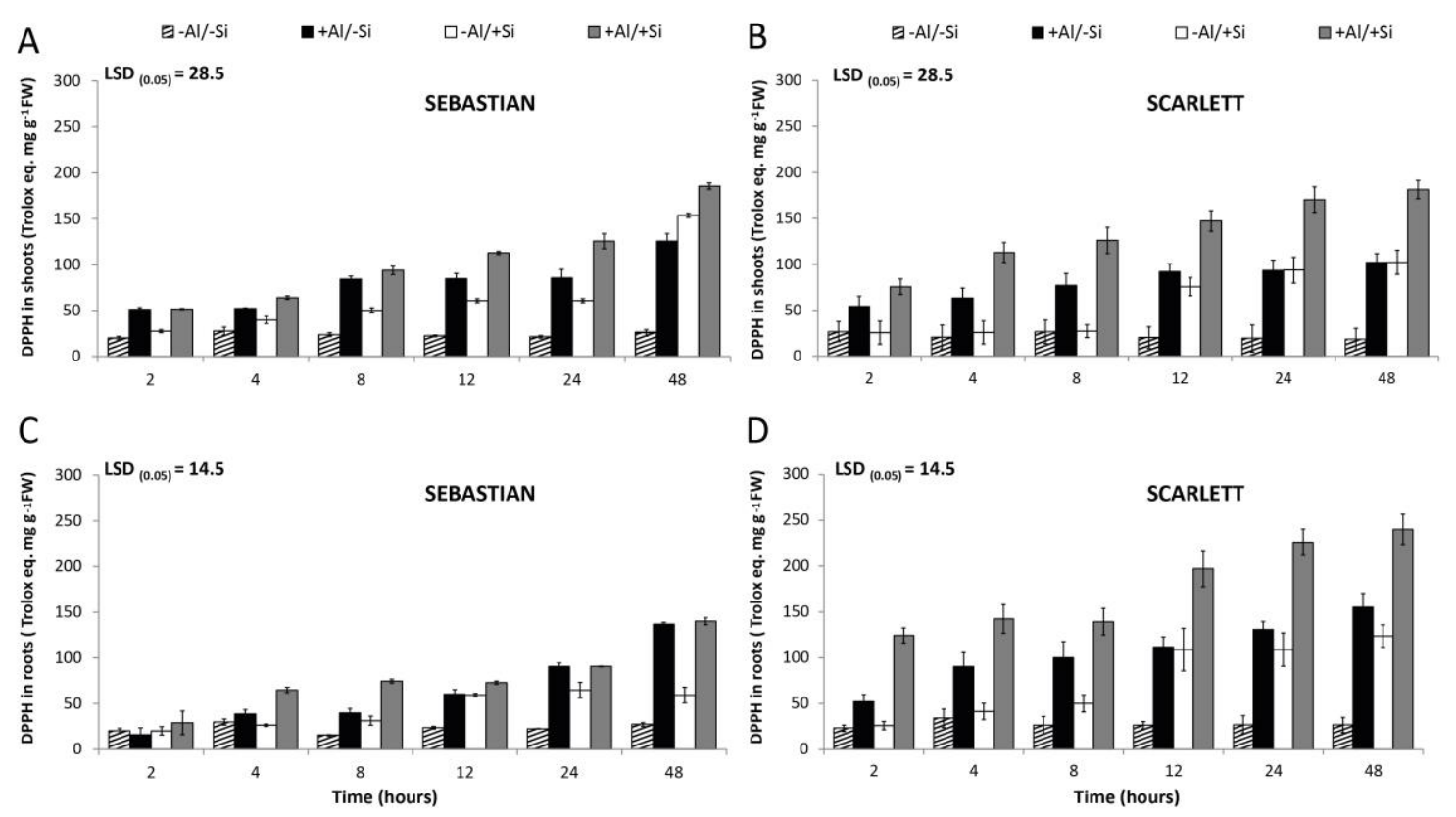

Figure 5. Free radical scavenging of shoots $(\mathbf{A}, \mathbf{B})$ and roots $(\mathbf{C}, \mathbf{D})$ in barley cv. 'Sebastian' (Al-tolerant) and Scarlett (Al-sensitive) harvested at 2, 4, 8, 12, 24, and $48 \mathrm{~h}$. The plants were subjected to $-\mathrm{Al}$ and $+\mathrm{Al}(0.2 \mathrm{mM})$ nutrient solution without $(-\mathrm{Si})$ or with $(+\mathrm{Si})$ supply of $2 \mathrm{mM} \mathrm{Si}$. Values correspond to the average of three replicates \pm standard deviation. Differences between treatments were examined using the LSD test $(p \leq 0.05)$.

A steady increase in the lipid peroxidation of both cultivars was found across all harvest times as a result of the application of $\mathrm{Al}$, and this increase was more apparent in the $\mathrm{Al}$ sensitive cultivar 'Scarlett' than in the Al tolerant cultivar 'Sebastian' (Figure 6). A positive correlation was found for both cultivars between Al uptake and lipid peroxidation in the roots ('Sebastian', $r=0.828 ; p \leq 0.01$; 'Scarlett', $r=0.546 ; p \leq 0.01$ ) and shoots ('Sebastian', $r=0.741 ; p \leq 0.01$; 'Scarlett', $r=0.713 ; p \leq 0.01$ ). For 'Sebastian', the highest increase of TBARS content relative to the control was observed after $12 \mathrm{~h}$, showing an increase of 54\% (shoots) and $46 \%$ (roots) due to $\mathrm{Al}$ addition (Figure $6 \mathrm{~A}, \mathrm{C}$ ). In contrast, the lowest TBARS concentration occurred at $48 \mathrm{~h}$ in plants treated simultaneously with $\mathrm{Si}$ and $\mathrm{Al}$. For 'Scarlett', the highest augment of TBARS relative to the control was observed at $48 \mathrm{~h}$ in the $\mathrm{Al}$ treatment, with an increase of $52 \%$ (shoots) and $45 \%$ (roots) relative to the control (Figure 6B,D). Silicon treatment significantly diminished lipid peroxidation in plants supplied with $\mathrm{Al}$, and the lowest TBARS concentration was registered at $48 \mathrm{~h}$ after treatment in both cultivars. Furthermore, a negative correlation was observed between Si uptake and lipid peroxidation in either roots ('Sebastian', $r=-0.701 ; p \leq 0.01$; 'Scarlett', $r=-0.299 ; p \leq 0.05$ ) or shoots ('Sebastian', $r=-0.655 ; p \leq 0.01$ ). 

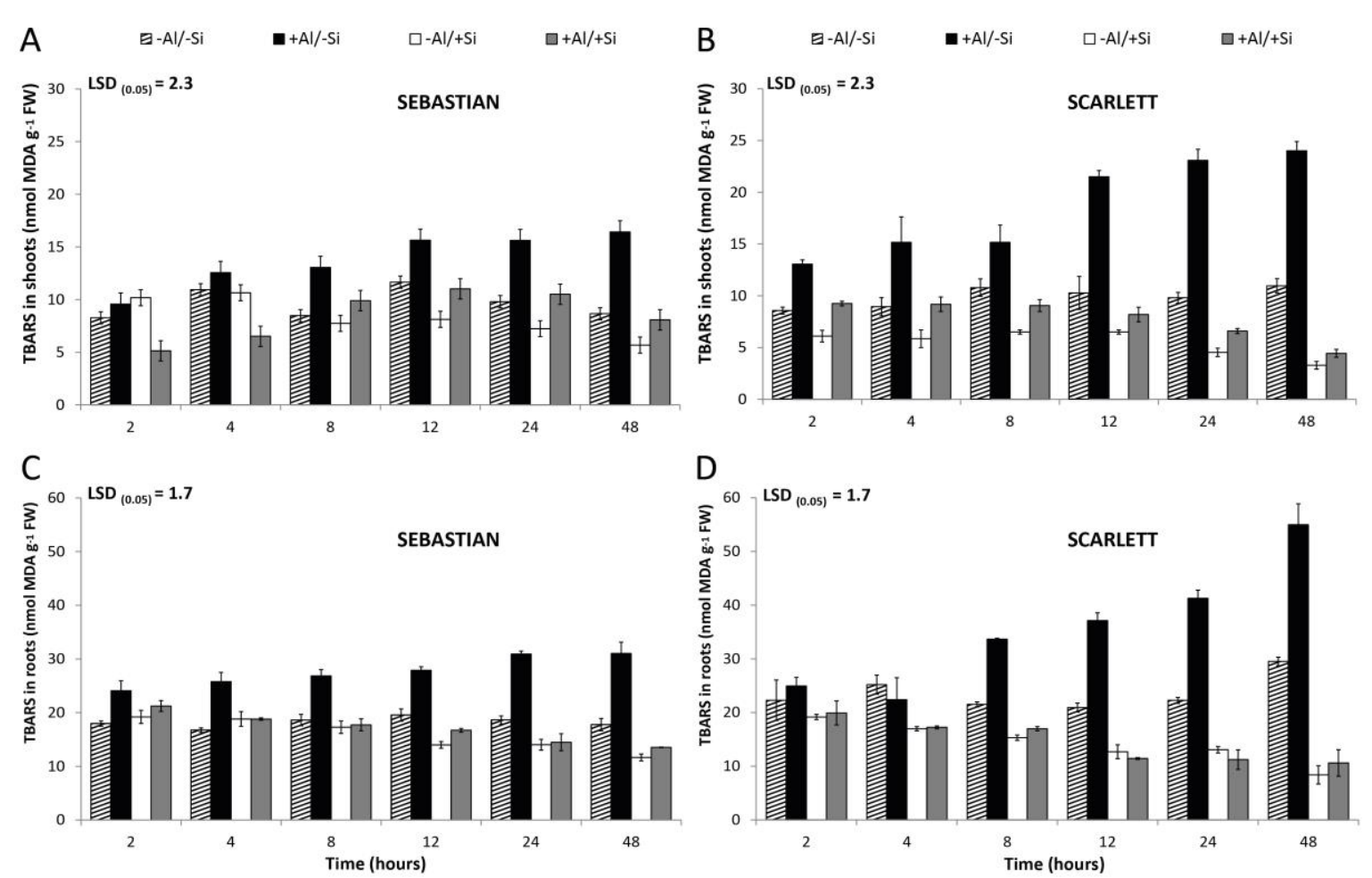

Figure 6. Lipid peroxidation of shoots (A,B) and roots (C,D) in barley cv. 'Sebastian' (Al-tolerant) and 'Scarlett' (Al-sensitive) harvested at 2, 4, 8, 12, 24, and $48 \mathrm{~h}$. The plants were subjected to $-\mathrm{Al}$ and $+\mathrm{Al}$ $(0.2 \mathrm{mM})$ nutrient solution without $(-\mathrm{Si})$ or with $(+\mathrm{Si})$ supply of $2 \mathrm{mM}$ Si. Values correspond to the average of three replicates \pm standard deviation. Differences between treatments were examined using the LSD test $(p \leq 0.05)$.

\section{Discussion}

Although numerous researches have shown that Si stimulates the growth and development of plants under Al stress [12,43,45], only very few studies have been undertaken using barley. So far, there have not been any studies conducted on the secondary metabolism response of barley to Si/Al interactions. This is the first report about the impact of $\mathrm{Si}$ on the production of phenolic compounds with antioxidant or structural functions in barley cultivated under $\mathrm{Al}$ stress conditions.

Previous studies have shown the differential accumulation of Al between different plant species exposed to Al stress $[4,56]$. In our study, barley cultivars showed rapid incorporation of Al into their tissues (Figure 1). However, 'Scarlett' exhibited the highest $\mathrm{Al}$ accumulation and translocation from roots to shoots (about 72\%). These findings denote the greater sensitivity of 'Scarlett' to Al toxicity compared with 'Sebastian', which is in agreement with previous reports on the differences in Al tolerance among genotypes [6,57].

We conducted our kinetic study over a period of only $48 \mathrm{~h}$, since metabolic disruptions at the physiological and biochemical level occur as early responses triggered by $\mathrm{Al}$ toxicity $[4,56]$. The metabolic responses induced by $\mathrm{Al}$ at the short-term could result in decreased yields and quality of crops, due to long-term alterations of plant homeostasis $[4,56,58]$. An increment in both the damage to lipid membranes (Figure 6) and the production of phenols (Figure 3) as a consequence of the addition of $\mathrm{Al}$ were found after the second hour of treatment. In addition, the $\mathrm{Al}$ concentration in the roots and shoots were found to be positively correlated with either lipid peroxidation or antioxidant activity in both cultivars, which is consistent with the informed by Xu et al. [59]. Thus, as Al triggered oxidative damage to biological membranes, the plants increased the production of phenolic compounds to counteract the stress induced by $\mathrm{Al}$, as had already been observed by Valentinuzzi et al. [60]. 
In the same way, an increase in the lignin staining intensity was observed in the roots at all harvest times in Al treated plants, compared with the control (Figure 4). In the Al sensitive cultivar 'Scarlett', the intensity of staining was stronger than in the $\mathrm{Al}$ tolerant cultivar 'Sebastian'. Ma et al. [61] also found higher lignin accumulation in an $\mathrm{Al}$ sensitive rice cultivar, compared to an $\mathrm{Al}$ tolerant rice cultivar; this effect was related with increased hydrogen peroxide production and peroxidase activity. Furthermore, You et al. [62] showed that the expression of lignin genes in the cell walls of soybean was induced by $\mathrm{Al}$ supply; this was associated with root growth inhibition by $\mathrm{Al}$ stress. Nevertheless, the mechanism involved in the accumulation of lignin in the roots induced by $\mathrm{Al}$ toxicity still needs to be clarified.

The shoot $\mathrm{Si}$ accumulation has been mainly associated to the root capacity to take up $\mathrm{Si}[12,28]$. We observed that $\mathrm{Si}$ taken up by barley roots was translocated rapidly (after $2 \mathrm{~h}$ ) to the shoots of both cultivars, irrespective of the $\mathrm{Al}$ addition (Figure 2) as expected considering that barley is a Si accumulator species [32-34,63]. Accordingly, considering the importance of the plant genetic predisposition to accumulate $\mathrm{Si}[29,64]$, molecular aspects related with the uptake and transport of $\mathrm{Si}$ in barley plants subjected to $\mathrm{Al}$ stress deserves to be investigated.

Silicon benefits have been demonstrated for plants grown under stress conditions, such as pest attack, lodging, nutrient imbalance, salinity, metal, water stress, and low temperatures [12-15]. In our study, the sole application of Si stimulated the antioxidant system of both barley cultivars, compared with the control treatment. In this way, the lipid peroxidation was reduced by $\mathrm{Si}$ in roots and shoots from $12 \mathrm{~h}$ for 'Sebastian', and at all harvest times for 'Scarlett', as shown in Figure 6. These responses might imply a direct effect of $\mathrm{Si}$ in attenuating the deleterious effect of low $\mathrm{pH}$ in the culture media ( $\mathrm{pH} 4.5)$, as barley is very sensitive to acid conditions.

Both the shoots and the roots of the Al sensitive cultivar 'Scarlett' showed an increase in the concentrations of phenols from the Si application after $24 \mathrm{~h}$ (Figure 3B,D). However, this effect was not detected in the Al tolerant cultivar 'Sebastian' (Figure $3 \mathrm{~A}, \mathrm{C}$ ). Moreover, structural phenols such as lignin also showed an increase in root staining intensity in both cultivars studied at all harvest times (Figure 4), when Si was applied. Our results suggest that there is a direct relationship between Si and phenolic metabolism, as has previously been proposed by Filha et al. [19], Shetty et al. [20], and Schaller et al. [21], but it seems that this effect is variable between cultivars. Based on this premise, further research is needed to clarify the mechanisms underlying the potential role of $\mathrm{Si}$ in the modulation of phenolic metabolism, and whether these mechanisms vary between different species and different cultivars.

There are evidences have shown that $\mathrm{Si}$ can counteract the effects of excess of certain metals (e.g., $\mathrm{Zn}, \mathrm{Fe}, \mathrm{Cu}, \mathrm{Cd}, \mathrm{Cr}, \mathrm{Mn}, \mathrm{As}$ ) [10,38-42] by promoting: (i) cell wall-binding [10], (ii) modification of gene expression of PAL enzyme [38], (iii) phenotypical structural alterations that increase root length [39], (iv) changes to the number of leaves per plant and leaf area [40], and (v) changes to the thickness of epidermal layers of the leaf [41]. With respect to Al toxicity in particular, some studies have proposed that Si may reduce plant stress by promoting: (i) increases in the solution $\mathrm{pH}$ [43], (ii) the formation of aluminosilicates in the growth media and cell wall $[43,65,66]$, (iii) the release of phenolic compounds by the root tips [47,60], (iv) increment of carotenoids and chlorophyll in leaves [67], and (v) stimulation of antioxidant enzyme activities and antioxidant compound production [23,44]. Nevertheless, there is still a controversial debate regarding the mechanisms implicated in the Si-mediated the attenuation of $\mathrm{Al}$ toxicity. In our study, when $\mathrm{Al}$ was applied in combination with $\mathrm{Si}$, both barley cultivars showed a decrease in oxidative damage at all harvest times, compared to those treated with $\mathrm{Al}$ alone (Figure 6). This reduction was accompanied by an improvement of the antioxidant capacity (Figure 5) and total phenol concentration (Figure 3). In this context, some studies have found an enhancement in the antioxidant system due to the action of Si under different stresses. Consequently, the increased production of flavonoids [47], activated antioxidant enzymes [17,23,44,46], decreased lipid peroxidation of the membranes [68], regulation of gene expression, and activation of key enzymes of the phenylpropanoid pathway $[16,20,44,69]$ have all been identified. 
Our results also showed that $\mathrm{Si}$ increased lignin accumulation, mainly in the roots, when treated with both $\mathrm{Al}$ and $\mathrm{Si}$ compared to control (Figure 4). This is in agreement with previous studies, that have shown a stress mitigation effect from $\mathrm{Si}$ due to stimulation of lignin production [19,70], and the alteration of lignin composition [23] under diverse stresses. Additionally, it has been demonstrated that $\mathrm{Si}$ increases the activities of lignin metabolic pathway enzymes such as peroxidase, polyphenol oxidase, and phenylalanine ammonia lyase $[20,25,69]$. This increase in lignin appears to be playing an important role in counteracting $\mathrm{Al}$ induced damage, since reactive oxygen species can react with lignin in the apoplast to generate signal molecules under stress conditions [71]. Moreover, Si may exert an important function in plant signaling by inducing changes in both the $\mathrm{C} / \mathrm{N}$ balance [11] and the lignification-related genes [24].

\section{Conclusions}

Silicon decreases $\mathrm{Al}$ uptake in barley plants by providing reductions in oxidative damage and improvements in antioxidant activity at the short-term. In addition, Si stimulated phenolic metabolism in $\mathrm{Al}$ stressed plants, as demonstrated by the increase in both the phenol concentrations and the lignin accumulation at the root level. Further studies are needed to clarify the function of $\mathrm{Si}$ in the modulation of phenylpropanoid pathway, as well as the potential role of $\mathrm{Si}$ induced lignin production in the generation of signaling molecules in barley cultivars grown under conditions of Al toxicity.

Supplementary Materials: The following are available online at http://www.mdpi.com/2073-4395/9/7/388/s1, Figure S1: Dry weight, length and lipid peroxidation in roots of different barley cultivars hydroponically grown without $(-\mathrm{Al})$ or with (+Al) supply of $0.2 \mathrm{mM}$ Al during 21 days.

Author Contributions: Data curation, I.V.; Formal analysis, I.V. and S.P.; Funding acquisition, P.C.; Investigation, P.C.; Methodology, I.V., S.P., and K.G.; Supervision, P.C.; Visualization, I.V.; Writing—original draft, I.V.; Writingreview \& editing, I.V., M.N., S.P., K.G., M.d.L.L.M., and P.C.

Funding: This study was supported by the FONDECYT project 1161326.

Acknowledgments: The authors acknowledge the Scientific and Technological Bioresource Nucleus of Universidad de La Frontera (BIOREN-UFRO) for providing access to specialized equipment for use in laser scanning confocal microscopy analysis. Furthermore, we are grateful to Dirección de Investigación of Universidad de La Frontera and MN thanks to the Serbian Ministry of Education, Science and Technological Development (OI-173028).

Conflicts of Interest: The authors declare no conflict of interest.

\section{References}

1. Jadhav, S.J.; Lutz, S.E.; Ghorpade, V.M.; Salunkhe, D.K. Barley: Chemistry and value-added processing. Crit. Rev. Food Sci. Nutr. 1998, 38, 123-171. [CrossRef] [PubMed]

2. Din, A.; Chughtai, M.F.J.; Khan, M.R.K.; Shahzad, A.; Khaliq, A.; Nasir, M.A. Nutritional and functional perspectives of barley $\beta$-glucan. Int. Food Res. J. 2018, 25, 1773-1784.

3. Gallardo, F.; Borie, F.; Alvear, M.; von Baer, E. Evaluation of aluminum tolerance of three barley cultivars by two short-term screening methods and field experiments. J. Soil Sci. Plant Nutr. 1999, 45, 713-719. [CrossRef]

4. Sade, H.; Meriga, B.; Surapu, V.; Gadi, J.; Sunita, M.S.L.; Suravajhala, P.; Kishor, P.K. Toxicity and tolerance of aluminum in plants: Tailoring plants to suit to acid soils. Biometals 2016, 29, 187-210. [CrossRef] [PubMed]

5. Singh, S.; Tripathi, D.K.; Singh, S.; Sharma, S.; Dubey, N.K.; Chauhan, D.K.; Vaculík, M. Toxicity of aluminium on various levels of plant cells and organism: A review. Environ. Exp. Bot. 2017, 137, 177-193. [CrossRef]

6. Cartes, P.; McManus, M.; Wulff-Zottele, C.; Leung, S.; Gutiérrez-Moraga, A.; Mora, M.L. Differential superoxide dismutase expression in ryegrass cultivars in response to short term aluminium stress. Plant Soil 2012, 350, 353-363. [CrossRef]

7. Kochian, L.V.; Hoekenga, O.A.; Piñeros, M.A. How do crop plants tolerate acid soils? Mechanisms of aluminum tolerance and phosphorous efficiency. Annu. Rev. Plant Biol. 2004, 55, 459-493. [CrossRef] 
8. Ishikawa, S.; Wagatsuma, T.; Sasaki, R.; Ofei-Manu, P. Comparison of the amount of citric and malic acids in Al media of seven plant species and two cultivars each in five plant species. Soil Sci. Plant Nutr. 2000, 46, 751-758. [CrossRef]

9. Ma, J.F.; Chen, Z.C.; Shen, R.F. Molecular mechanisms of Al tolerance in gramineous plants. Plant Soil 2014, 381, 1-12. [CrossRef]

10. Song, A.; Li, P.; Li, Z.; Fan, F.; Nikolic, M.; Liang, Y. The alleviation of zinc toxicity by silicon is related to zinc transport and antioxidative reactions in rice. Plant Soil 2011, 344, 319-333. [CrossRef]

11. Detmann, K.C.; Araújo, W.L.; Martins, S.C.; Sanglard, L.M.; Reis, J.V.; Detmann, E.; DaMatta, F.M. Silicon nutrition increases grain yield, which, in turn, exerts a feed-forward stimulation of photosynthetic rates via enhanced mesophyll conductance and alters primary metabolism in rice. New Phytol. 2012, 196, 752-762. [CrossRef] [PubMed]

12. Pontigo, S.; Ribera, A.; Gianfreda, L.; Mora, M.L.; Nikolic, M.; Cartes, P. Silicon in vascular plants: Uptake, transport and its influence on mineral stress under acidic conditions. Planta 2015, 242, 23-37. [CrossRef] [PubMed]

13. Bakhat, H.F.; Bibi, N.; Zia, Z.; Abbas, S.; Hammad, H.M.; Fahad, S.; Saeed, S. Silicon mitigates biotic stresses in crop plants: A review. Crop Prot. 2018, 104, 21-34. [CrossRef]

14. Etesami, H.; Jeong, B.R. Silicon (Si): Review and future prospects on the action mechanisms in alleviating biotic and abiotic stresses in plants. Ecotoxicol. Environ. Saf. 2018, 147, 881-896. [CrossRef] [PubMed]

15. Malhotra, C.; Kapoor, R.T. Silicon: A Sustainable Tool in Abiotic Stress Tolerance in Plants. In Plant Abiotic Stress Tolerance; Springer: Cham, Switzerland, 2019; pp. 333-356. [CrossRef]

16. Araujo, M.; Rios, J.; Silva, E.; Rodrigues, F. Silicon alleviates the changes in the source-sink relationship of wheat plants infected by Pyricularia oryzae. Phytopathology 2019. [CrossRef] [PubMed]

17. Abd_Allah, E.F.; Hashem, A.; Alam, P.; Ahmad, P. Silicon Alleviates Nickel-Induced Oxidative Stress by Regulating Antioxidant Defense and Glyoxalase Systems in Mustard Plants. J. Plant Growth Regul. 2019, 1-14. [CrossRef]

18. Kostic, L.; Nikolic, N.; Bosnic, D.; Samardzic, J.; Nikolic, M. Silicon increases phosphorus (P) uptake by wheat under low P acid soil conditions. Plant Soil 2017, 419, 447-455. [CrossRef]

19. Filha, M.X.; Rodrigues, F.A.; Domiciano, G.P.; Oliveira, H.V.; Silveira, P.R.; Moreira, W.R. Wheat resistance to leaf blast mediated by silicon. Australas. Plant Pathol. 2011, 40, 28-38. [CrossRef]

20. Shetty, R.; Fretté, X.; Jensen, B.; Shetty, N.P.; Jensen, J.D.; Jørgensen, H.J.L.; Christensen, L.P. Silicon-induced changes in antifungal phenolic acids, flavonoids, and key phenylpropanoid pathway genes during the interaction between miniature roses and the biotrophic pathogen Podosphaera pannosa. Plant Physiol. 2011, 157, 2194-2205. [CrossRef]

21. Schaller, J.; Brackhage, C.; Dudel, E.G. Silicon availability changes structural carbon ratio and phenol content of grasses. Environ. Exp. Bot. 2012, 77, 283-287. [CrossRef]

22. Maksimović, D.J.; Bogdanović, J.; Maksimović, V.; Nikolic, M. Silicon modulates the metabolism and utilization of phenolic compounds in cucumber (Cucumis sativus L.) grown at excess manganese. J. Soil Sci. Plant Nutr. 2007, 170, 739-744. [CrossRef]

23. Ribera-Fonseca, A.; Rumpel, C.; Mora, M.L.; Nikolic, M.; Cartes, P. Sodium silicate and calcium silicate differentially affect silicon and aluminium uptake, antioxidant performance and phenolics metabolism of ryegrass in an acid Andisol. Crop Pasture Sci. 2018, 69, 205-215. [CrossRef]

24. Fleck, A.T.; Nye, T.; Repenning, C.; Stahl, F.; Zahn, M.; Schenk, M.K. Silicon enhances suberization and lignification in roots of rice (Oryza sativa). J. Exp. Bot. 2010, 62, 2001-2011. [CrossRef] [PubMed]

25. Cai, K.; Gao, D.; Luo, S.; Zeng, R.; Yang, J.; Zhu, X. Physiological and cytological mechanisms of silicon-induced resistance in rice against blast disease. Physiol. Plant. 2008, 134, 324-333. [CrossRef] [PubMed]

26. Inanaga, S.; Okasaka, A.; Tanaka, S. Does silicon exist in association with organic compounds in rice plant? Soil Sci. Plant Nutr. 1995, 41, 111-117. [CrossRef]

27. Guerriero, G.; Hausman, J.F.; Legay, S. Silicon and the plant extracellular matrix. Front. Plant Sci. 2016, 7, 463. [CrossRef] [PubMed]

28. Ma, J.F.; Yamaji, N.A. Cooperative system of silicon transport in plants. Trends Plant Sci. 2015, 20, 435-442. [CrossRef] [PubMed] 
29. Deshmukh, R.; Bélanger, R.R. Molecular evolution of aquaporins and silicon influx in plants. Funct. Ecol. 2016, 30, 1277-1285. [CrossRef]

30. Ma, J.F.; Yamaji, N.; Tamai, K.; Mitani, N. Genotypic difference in silicon uptake and expression of silicon transporter genes in rice. Plant Physiol. 2007, 145, 919-924. [CrossRef]

31. Hodson, M.J.; White, P.J.; Mead, A.; Broadley, M.R. Phylogenetic variation in the silicon composition of plants. Ann. Bot. 2005, 96, 1027-1046. [CrossRef]

32. Chiba, Y.; Mitani, N.; Yamaji, N.; Ma, J.F. HvLsi1 is a silicon influx transporter in barley. Plant J. 2009, 57, 810-818. [CrossRef] [PubMed]

33. Mitani, N.; Chiba, Y.; Yamaji, N.; Ma, J.F. Identification and characterization of maize and barley Lsi2-like silicon efflux transporters reveals a distinct silicon uptake system from that in rice. Plant Cell 2009, 21, 2133-2142. [CrossRef] [PubMed]

34. Yamaji, N.; Chiba, Y.; Mitani-Ueno, N.; Ma, J.F. Functional characterization of a silicon transporter gene implicated in silicon distribution in barley. Plant Physiol. 2012, 160, 1491-1497. [CrossRef] [PubMed]

35. Deshmukh, R.K.; Vivancos, J.; Guérin, V.; Sonah, H.; Labbé, C.; Belzile, F.; Bélanger, R.R. Identification and functional characterization of silicon transporters in soybean using comparative genomics of major intrinsic proteins in Arabidopsis and rice. Plant Mol. Biol. 2013, 83, 303-315. [CrossRef] [PubMed]

36. Deshmukh, R.K.; Vivancos, J.; Ramakrishnan, G.; Guérin, V.; Carpentier, G.; Sonah, H.; Bélanger, R.R. A precise spacing between the NPA domains of aquaporins is essential for silicon permeability in plants. Plant J. 2015, 83, 489-500. [CrossRef] [PubMed]

37. Vatansever, R.; Ozyigit, I.I.; Filiz, E.; Gozukara, N. Genome-wide exploration of silicon (Si) transporter genes, Lsi1 and Lsi2 in plants; insights into Si-accumulation status/capacity of plants. BioMetals 2017, 30, 185-200. [CrossRef] [PubMed]

38. Khandekar, S.; Leisner, S. Soluble silicon modulates expression of Arabidopsis thaliana genes involved in copper stress. J. Plant Physiol. 2011, 168, 699-705. [CrossRef]

39. Vaculík, M.; Lux, A.; Luxová, M.; Tanimoto, E.; Lichtscheidl, I. Silicon mitigates cadmium inhibitory effects in young maize plants. Environ. Exp. Bot. 2009, 67, 52-58. [CrossRef]

40. Anwaa, S.A.; Ali, S.; Ishaque, W.; Farid, M.; Farooq, M.A.; Sharif, M. Silicon (Si) alleviates cotton (Gossypium hirsutum L.) from zinc (Zn) toxicity stress by limiting Zn uptake and oxidative damage. Environ. Sci. Pollut. Res. Int. 2015, 22, 3441-3450. [CrossRef]

41. Doncheva, S.N.; Poschenrieder, C.; Stoyanova, Z.; Georgieva, K.; Velichkova, M.; Barceló, J. Silicon amelioration of manganese toxicity in Mn-sensitive and Mn-tolerant maize varieties. Environ. Exp. Bot. 2009, 65, 189-197. [CrossRef]

42. Bhat, J.A.; Shivaraj, S.M.; Singh, P.; Navadagi, D.B.; Tripathi, D.K.; Dash, P.K.; Solanke, A.U.; Sonah, H.; Deshmukh, R. Role of Silicon in Mitigation of Heavy Metal Stresses in Crop Plants. Plants 2019, 8, 71. [CrossRef] [PubMed]

43. Cocker, K.M.; Evans, D.E.; Hodson, M.J. The amelioration of aluminium toxicity by silicon in higher plants: Solution chemistry or an in plants mechanism? Physiol. Plant. 1998, 104, 608-614. [CrossRef]

44. Pontigo, S.; Godoy, K.; Jiménez, H.; Gutiérrez-Moraga, A.; Mora, M.L.; Cartes, P. Silicon-mediated alleviation of aluminum toxicity by modulation of $\mathrm{Al} / \mathrm{Si}$ uptake and antioxidant performance in ryegrass plants. Front. Plant Sci. 2017, 8, 642. [CrossRef] [PubMed]

45. Tripathi, D.K.; Bashri, G.; Shweta, S.; Ahmad, P.; Singh, V.P. Efficacy of silicon against aluminum toxicity in plants: An overview. In Silicon in Plants: Advances and Future Prospects; CRC Press: Boca Raton, FL, USA, 2017; Volume 1, pp. 355-366.

46. Balakhnina, T.I.; Matichenkov, V.V.; Wlodarczyk, T.; Borkowska, A.; Nosalewicz, M.; Fomina, I.R. Effects of silicon on growth processes and adaptive potential of barley plants under optimal soil watering and flooding. Plant Growth Regul. 2012, 67, 35-43. [CrossRef]

47. Kidd, P.S.; Llugany, M.; Poschenrieder, C.H.; Gunse, B.; Barcelo, J. The role of root exudates in aluminium resistance and silicon-induced amelioration of aluminium toxicity in three varieties of maize (Zea mays L.). J. Exp. Bot. 2001, 52, 1339-1352. [CrossRef] [PubMed]

48. Taylor, G.J.; Foy, C.D. Mechanisms of aluminum tolerance in Triticum aestivum L. (wheat). II. Differential pH induced by spring cultivars in nutrient solutions. Appl. Plant Sci. 1985, 702-706. [CrossRef] 
49. Shaff, J.E.; Schultz, B.A.; Craft, E.J.; Clark, R.T.; Kochian, L.V. GEOCHEM-EZ: A chemical speciation program with greater power and flexibility. Plant Soil 2010, 330, 207-214. [CrossRef]

50. Sadzawka, A.; Carrasco, M.; Demane, R.; Flores, H.; Grez, R.; Mora, M.L.; Neaman, A. Métodos de análisis de tejidos vegetales. Serie Actas INIA 2007, 40, 140.

51. Pavlovic, J.; Samardzic, J.; Maksimović, V.; Timotijevic, G.; Stevic, N.; Laursen, K.H.; Nikolic, M. Silicon alleviates iron deficiency in cucumber by promoting mobilization of iron in the root apoplast. New Phytol. 2013, 198, 1096-1107. [CrossRef]

52. Slinkard, K.; Singleton, V.L. Total phenol analysis: Automation and comparison with manual methods. Am. J. Enol. Vitic. 1977, 28, 49-55.

53. Chinnici, F.; Bendini, A.; Gaiani, A.; Riponi, C. Radical scavenging activities of peels and pulps from cv. Golden Delicious apples as related to their phenolic composition. J. Agric. Food Chem. 2004, 52, 4684-4689. [CrossRef] [PubMed]

54. Du, Z.; Bramlage, W.J. Modified thiobarbituric acid assay for measuring lipid oxidation in sugar-rich plant tissue extracts. J. Agric. Food Chem. 1992, 40, 1566-1570. [CrossRef]

55. Sant'Anna, V.; Gurak, P.D.; Marczak, L.D.F.; Tessaro, I.C. Tracking bioactive compounds with colour changes in foods-A review. Dyes Pigm. 2013, 98, 601-608. [CrossRef]

56. Kochian, L.V.; Piñeros, M.A.; Liu, J.; Magalhaes, J.V. Plant adaptation to acid soils: The molecular basis for crop aluminum resistance. Annu. Rev. Plant Biol. 2015, 66, 571-598. [CrossRef] [PubMed]

57. Du, B.; Nian, H.; Zhang, Z.; Yang, C. Effects of aluminum on superoxide dismutase and peroxidase activities, and lipid peroxidation in the roots and calluses of soybeans differing in aluminum tolerance. Acta Physiol. Plant. 2010, 32, 883-890. [CrossRef]

58. Horst, W.J.; Wang, Y.; Eticha, D. The role of the root apoplast in aluminium-induced inhibition of root elongation and in aluminium resistance of plants: A review. Ann. Bot. 2010, 106, 185-197. [CrossRef] [PubMed]

59. Xu, F.J.; Li, G.; Jin, C.W.; Liu, W.J.; Zhang, S.S.; Zhang, Y.S.; Lin, X.Y. Aluminum-induced changes in reactive oxygen species accumulation, lipid peroxidation and antioxidant capacity in wheat root tips. Biol. Plant. 2012, 56, 89-96. [CrossRef]

60. Valentinuzzi, F.; Cesco, S.; Tomasi, N.; Mimmo, T. Effect of aluminium exposure on the release of organic acids and genistein from the roots of Lupinus albus L. plants. Rhizosphere 2016, 1, 29-32. [CrossRef]

61. Ma, B.; Gao, L.; Zhang, H.; Cui, J.; Shen, Z. Aluminum-induced oxidative stress and changes in antioxidant defenses in the roots of rice varieties differing in Al tolerance. Plant Cell Rep. 2012, 31, 687-696. [CrossRef]

62. You, J.; Zhang, H.; Liu, N.; Gao, L.; Kong, L.; Yang, Z. Transcriptomic responses to aluminum stress in soybean roots. Genome 2011, 54, 923-933. [CrossRef]

63. Nikolic, M.; Nikolic, N.; Liang, Y.; Kirkby, E.A.; Römheld, V. Germanium-68 as an adequate tracer for silicon transport in plants. Characterization of silicon uptake in different crop species. Plant Physiol. 2007, 143, 495-503. [CrossRef] [PubMed]

64. Ouellette, S.; Goyette, M.H.; Labbé, C.; Laur, J.; Gaudreau, L.; Gosselin, A.; Bélanger, R.R. Silicon transporters and effects of silicon amendments in strawberry under high tunnel and field conditions. Front. Plant Sci. 2017, 8, 949. [CrossRef] [PubMed]

65. Ma, J.F.; Sasaki, M.; Matsumoto, H. Al-induced inhibition of root elongation in corn, Zea mays L. is overcome by Si addition. Plant Soil 1997, 188, 171-176. [CrossRef]

66. Wang, Y.; Stass, A.; Horst, W.J. Apoplastic binding of aluminum is involved in silicon-induced amelioration of aluminum toxicity in maize. Plant Physiol. 2004, 136, 3762-3770. [CrossRef] [PubMed]

67. Singh, V.P.; Tripathi, D.K.; Kumar, D.; Chauhan, D.K. Influence of exogenous silicon addition on aluminium tolerance in rice seedlings. Biol. Trace Elem. Res. 2011, 144, 1260-1274. [CrossRef] [PubMed]

68. Hajiboland, R.; Joudmand, A.; Aliasgharzad, N.; Tolrá, R.; Poschenrieder, C. Arbuscular mycorrhizal fungi alleviate low-temperature stress and increase freezing resistance as a substitute for acclimation treatment in barley. Crop Pasture Sci. 2019. [CrossRef]

69. Song, A.; Xue, G.; Cui, P.; Fan, F.; Liu, H.; Yin, C.; Liang, Y. The role of silicon in enhancing resistance to bacterial blight of hydroponic-and soil-cultured rice. Sci. Rep. 2016, 6, 24640. [CrossRef]

70. Zhang, Y.M.; Li, Y.; Chen, W.F.; Wang, E.T.; Tian, C.F.; Li, Q.Q.; Chen, W.X. Biodiversity and biogeography of rhizobia associated with soybean plants grown in the North China Plain. Appl. Environ. Microbiol. 2011, 77, 6331-6342. [CrossRef] 
71. Jouanin, L.; Lapierre, C. Lignins: Biosynthesis, Biodegradation and Bioengineering; Academic Press: Cambridge, UK, USA, 2012; Volume 61.

(c)

(C) 2019 by the authors. Licensee MDPI, Basel, Switzerland. This article is an open access article distributed under the terms and conditions of the Creative Commons Attribution (CC BY) license (http://creativecommons.org/licenses/by/4.0/). 